\title{
Ankylosing spondylitis: an autoimmune disease?
}

\author{
H-J Lakomek, M Plomann, C Specker, M Schwochau
}

\begin{abstract}
Identification of several autoantibodies in serum samples from patients with ankylosing spondylitis or suspected ankylosing spondylitis is reported. Five antibodies associated with ankylosing spondylitis were identified by applying cytoimmunofluorescence and immunoblotting techniques to antigen pools from insect tissue. At least one of these antibodies was found in $\mathbf{8 2} \%$ of serum samples from patients with ankylosing spondylitis.

A $36 \mathrm{kD}$ drosophila antigen, which showed the most common and most dominant reaction, was further purified and isolated. Thirty two (34\%) of the serum samples from 95 patients with definite ankylosing spondylitis and $12(28 \%)$ of the serum samples from 43 patients with suspected ankylosing spondylitis reacted with this antigen. Antibodies purified from the $36 \mathrm{kD}$ antigen reacted specifically with a $69 \mathrm{kD}$ antigen present in separations of total protein preparations from human lymphocytes and HeLa cells.
\end{abstract}

The $36 \mathrm{kD}$ antibody was not found in 29 patients with rheumatoid arthritis nor in $\mathbf{3 8}$ apparently healthy controls. The prevalence of the $36 \mathrm{kD}$ antibody was comparable in HLA-B27 positive and negative patients. In addition, the same immunoreaction was found in patients with so called 'seronegative' spondylarthropathies, particularly of the ankylosing spondylitis-type, suggesting that this antibody is specific for ankylosing spondylitis or other 'seronegative' spondylarthropathies with the typical clinical and radiological changes of ankylosing spondylitis.

Department of Medicine, Endocrinology and Rheumatology,

Heinrich-Heine-

Universität Düsseldorf,

D-4000 Düsseldorf,

Germany

H-J Lakomek

C Specker

Institute for Genetics, Heinrich-Heine-

Universität Düsseldorf, D-4000 Düsseldorf, Germany

M Plomann

M Schwochau

Correspondence to:

Dr H-J Lakomek,

Klinik für Rheumatologie,

Physikalische Medizin und

Endokrinologie,

Klinikum Minden,

D-4950 Minden, Germany.

Accepted for publication

4 September 1990
Ankylosing spondylitis is the most common 'seronegative' spondylarthropathy. The low sensitivity of the New York criteria for the diagnosis of ankylosing spondylitis, ${ }^{12}$ especially in the early stages of the disease, and the lack of specific serological markers cause problems with diagnosis. ${ }^{3-8}$ Figure 1 shows a representative spectrum of rheumatic diseases reported in the Düsseldorfer Rheumaregister, a database comprising about 2000 patients. ${ }^{9}$ In comparison with the other diseases ankylosing spondylitis shows the highest proportion of suspected diagnoses. Application of serological parameters specific for ankylosing spondylitis could lead to an earlier diagnosis of the disease with higher confidence and in greater number.

In 1984 an antibody specific for ankylosing spondylitis, which reacted with the $93 \mathrm{D}$ heat shock puff of polythene chromosomes from

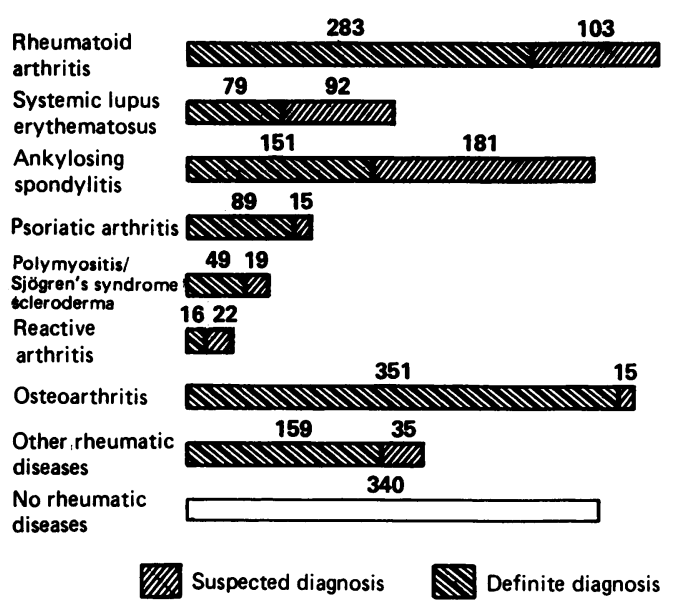

Figure 1 Spectrum of diagnoses in the Düsseldorf database for rheumatic diseases (1999 diagnoses in 1738 patients).

larval salivary glands of Drosophila melanogaster, was first described. ${ }^{10}$ In 1987 four additional insect antigens were identified $(36,45,52$, and $74 \mathrm{kD}$ ), which reacted specifically with antibodies present in the serum of patients with ankylosing spondylitis. ${ }^{11}$ Cytoimmunofluorescence and immunoblotting techniques showed that at least one of these antibodies was present in $82 \%$ of all patients with definite ankylosing spondylitis and patients with suspected disease as well.

Since $1973^{6}$ the strong correlation between ankylosing spondylitis and the HLA-B27 haplotype has been well recorded. No difference, however, was found between the nucleotide sequence of HLA-B27 genes from a healthy subject and from a patient with ankylosing spondylitis. ${ }^{12}$ The structural identity of the HLA-B27 protein molecules in patients with ankylosing spondylitis and normal subjects has also been reported. ${ }^{13}$

The prevalence of ankylosing spondylitis was first estimated by De Blecourt in $1961^{5}$ to be $0.2 \%$ in men and $0.03 \%$ in women. In 1975 Calin and Fries calculated that $1.6 \%$ of the white population probably develop ankylosing spondylitis, based on the fact that the HLA-B27 haplotype is found in $8 \%$ of the white population. ${ }^{8}$ An improved diagnosis based on serological data would reduce this large number of apparently undiagnosed patients.

Here we report the identification of xenotypic and homotypic antigens reacting with antibodies specifically present in the serum of patients with ankylosing spondylitis, thus proving ankylosing spondylitis to be an autoimmune disease. 


\section{Materials and methods SERUM SAMPLES}

All serum samples were collected in the department of medicine $C$, endocrinology and rheumatology at the Heinrich-Heine University Düsseldorf, FRG. Diagnosis of ankylosing spondylitis and seronegative spondylarthropathies was performed according to the New York criteria ${ }^{2}$ and of rheumatoid arthritis according to the American Rheumatism Association criteria. ${ }^{14}$ All patients' serum samples were tested by counterimmunoelectrophoresis for the absence of antibodies to extractable nuclear antigens-for example, RNP, Sm, SSA, $\mathrm{SSB}$. The serum samples were stored at $-80^{\circ} \mathrm{C}$ and diluted in phosphate buffered saline before use.

\section{CELL CULTURE}

The stable KC cell line derived from Drosophila melanogaster embryos was cultured at $25^{\circ} \mathrm{C}$ and suspended in medium D-22 free from serum. ${ }^{15} 16$ The stable $\mathrm{H}-33$ cell line from $D$ hydei embryos was cultured at $25^{\circ} \mathrm{C}$ in a medium supplemented with $10 \%$ fetal calf serum. ${ }^{17}{ }^{18} \mathrm{HeLa} \mathrm{S3}$ cells were cultured at $37^{\circ} \mathrm{C}$ suspended in a modified minimum essential medium containing L-glutamine, non-essential amino acids, fetal bovine serum, antibiotics, but no sodium bicarbonate. ${ }^{1920}$

\section{HARVESTING OF CELLS}

Lymphocytes were isolated from heparinised human venous blood provided by Professor Brüster (Institut für Blutgerinnungswesen und Transfusionsforshung, Heinrich-Heine-Universität, Düsseldorf) by differential centrifugation on a Ficoll-Paque solution $(\varrho=1 \cdot 1 \mathrm{~g} / \mathrm{ml}) .^{21} 22$ After recovery from the interface they were subjected twice to a short washing step with lymphocyte culture medium RPMI. HeLa, $\mathrm{H}-33$, and $\mathrm{KC}$ cells were harvested by centrifugation and washed twice in balanced salt solution.

\section{GENERAL PROCEDURE FOR TOTAL PROTEIN PREPARATION}

Most essential for reproducible isolation of undegraded material is the immediate lysis of the cell suspension or tissue (pulverised in liquid nitrogen) in the presence of sarcosyl, urea, and $\beta$-mercaptoethanol in a tight fitting Dounce homogeniser at $60-70^{\circ} \mathrm{C}$. Subsequent separation from nucleic acids and polysaccharides is achieved by centrifugation in a $\mathrm{CsCl}$ solution with a final density of about $1 \cdot 6 \mathrm{~g} / \mathrm{ml}$. The resulting float contains all peptides except for a few dense glycoproteins and can be stored below $-15^{\circ} \mathrm{C}$ undegraded for any length of time. For good and reproducible electrophoretic separations of the isolated antigens it is necessary to remove most of the sarcosyl and $\mathrm{CsCl}$. This is achieved by quick ( $2 \times 30$ minutes) dialysis against a buffer (containing a low concentration of the ions defining the stacking gel conditions applied in the subsequent sodium dodecylsulphate-polyacrylamide gel electro- phoresis (SDS-PAGE)) at the lowest possible temperature in the presence of a non-ionic detergent in a flabby dialysis bag (measuring no more than $2 \mathrm{~mm}$ in height when lying on a flat support).

\section{PREPARATION OF TOTAL PROTEIN FROM}

\section{LYMPHOCYTES, KC, H-33, OR HeLa CELLS}

The following two buffers were used: buffer $A$ : $6 \mathrm{M}$ urea, $0 \cdot 1 \mathrm{M} \mathrm{NaCl}, 5 \% \beta$-mercaptoethanol, $1 \%$ sarcosyl, $10 \mathrm{mM}$ TRIS/HCl pH 7·2; buffer B: as buffer A with sarcosyl replaced by $3 \%$ Nonidet P-40. After homogenisation in buffer A the different lysates were heated to $60^{\circ} \mathrm{C}$ for 10 minutes. The proteins were then collected as a float after one hour's centrifugation at 30000 rpm (Beckman SW60 rotor $=120000 \mathrm{~g}$ ) in $\mathrm{CsCl}$ (final density $1.6 \mathrm{~g} / \mathrm{ml}$ ). The protein float was dissolved in buffer $\mathrm{B}$ and dialysed against TRIS/ $\mathrm{HCl}$ buffer ( $25 \mathrm{mM}, \mathrm{pH} \mathrm{7 \cdot 4)}$ and, finally, precipitated with ethanol.

\section{IMMUNOBLOTS}

The proteins were separated electrophoretically in linear pore gradient disc gels $(10 \%-20 \%$ polyacrylamide, $2 \mathrm{~mm}$ thick) in the presence of urea $(4 \mathrm{~mol} / \mathrm{l})$ and sodium dodecyl sulphate $(0 \cdot 1 \%) .{ }^{23}$ The protein separations were blotted to nitrocellulose sheets (semidry ${ }^{24}$ ); transfer results were visualised by staining with ponceau $S$. The sheets were then cut into strips and incubated with human serum samples diluted 1:50 in phosphate buffered saline after blocking the nitrocellulose with bovine serum albumin $(0 \cdot 1 \%)$ and Nonidet P-40 (1\%). Immunoreactions were visualised by a biotinylated antihuman immunoglobulin (RPN 1003; Amersham), a streptavidin-peroxidase complex (RPN 1051; Amersham), and diaminobenzidine/ $\mathrm{H}_{2} \mathrm{O}_{2}$ or a fluorescein isothiocyanate conjugated sheep antihuman immunoglobulin (MF 01, Wellcome).

\section{PURIFICATION OF ANTIBODIES}

Except for the visualisation the protein blots were treated like immunoblots. The band containing the antibody-antigen complex was cut out. The antibodies were eluted for 15 minutes with $3 \mathrm{M}$ potassium thiocyanate and $0.1 \%$ bovine serum albumin in phosphate buffered saline and centrifuged in Centricon microconcentrators (Amicon) for desalting and concentration. ${ }^{25} 26$ The purified antibody solution was stored at $8^{\circ} \mathrm{C}$.

\section{TWO DIMENSIONAL ELECTROPHORESIS}

Proteins were focused in either gel rods or horizontal gels containing $9 \mathrm{M}$ urea, $2 \%$ Nonidet $\mathrm{P}-40$, and $2 \%$ ampholytes (pH 3.5-10) until the basic marker protein cytochrome $c$ reached the cathodic end. Before separation according to molecular weight using SDS-PAGE the gels were equilibrated in a buffer containing $10 \%$ glycerol, $2 \%$ sodium dodecyl sulphate, $5 \%$ $\beta$-mercaptoethanol, and $60 \mathrm{mM}$ TRIS/ $\mathrm{HCl}, \mathrm{pH}$ $6 \cdot 8$, for one hour. ${ }^{27-30}$ 
Results

In immunoblotting experiments we found a strong immune response with the $36 \mathrm{kD}$ drosophila protein in 32 (34\%) serum samples from patients with definite ankylosing spondylitis and in $12(28 \%)$ samples from patients with suspected ankylosing spondylitis (table, fig 2). Immunoreactions of this type were identical in protein preparations from serum free cultured $\mathrm{KC}$ cells and from fetal calf serum supplemented H-33 cells.

To prove the specificity of the antibody to the $36 \mathrm{kD}$ antigen we tested several serum samples from patients with other 'seronegative' spondylarthropathies-for example, psoriatic arthritis, Crohn's disease-and other systemic rheumatic diseases - for example, rheumatoid arthritis. As shown in the table $15(44 \%)$ of 34 serum samples from patients with 'seronegative' spondylarthropathies with diagnosed ankylosing spondylitis and only two (13\%) of 15 samples from patients with other 'seronegative' arthropathies not of the ankylosing spondylitis type reacted with the $36 \mathrm{kD}$ antigen, whereas

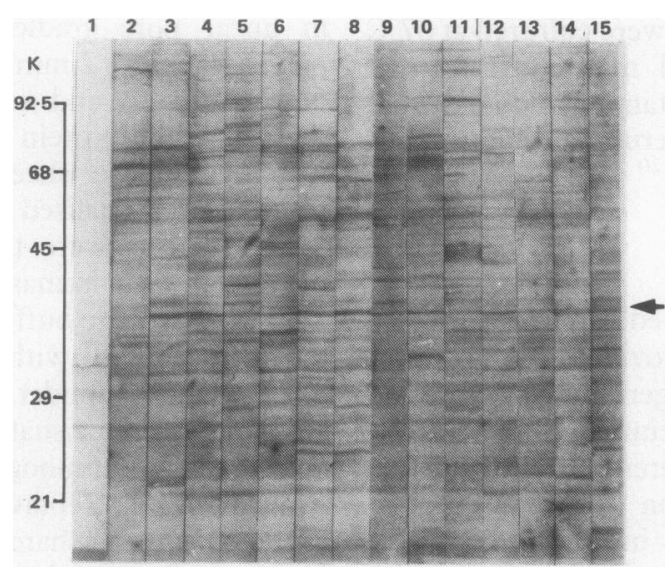

Figure 2 Staining of a $36 \mathrm{kD} \mathrm{KC}$ cell protein specific for ankylosing spondylitis. Western blot of a separation of a total protein preparation from the Drosophila melanogaster embryonic $K C$ cell line incubated with serum from 13 patients with ankylosing spondylitis (lanes 3-15) and pooled normal control serum (lane 2). The reactions were visualised by a biotinylated secondary antibody, a streptavidinperoxidase complex, and diaminobenzidine. Serum samples from the patients show a specific reaction with a $36 k D$ protein (arrow). Lane 1, the control, shows the reaction of the secondary antibody alone. The faint bands at $36 \mathrm{kD}$ visible in lanes 1 and 2 result from a cross reaction with the secondary antibody. These as well as most of the other bands cannot be seen in reactions with a fluorescein isothiocyanate conjugated sheep antihuman immunoglobulin antibody (MF 01 Wellcome) as shown in ref 11.

Prevalence of antibodies to the Drosophila melanogaster $36 \mathrm{kD}$ antigen in serum samples from patients with various rheumatic diseases

\begin{tabular}{lll}
\hline Diagnoses & $\begin{array}{l}\text { Total number } \\
\text { of tested } \\
\text { serum samples }\end{array}$ & $\begin{array}{l}\text { No (\%) showing } \\
\text { positive reaction } \\
\text { with the } \\
36 \text { kD antigen }\end{array}$ \\
\hline Definite AS * & 95 & $32(34)$ \\
Suspected AS & 43 & $12(28)$ \\
Definite and suspected AS & 120 & $42(35)$ \\
HLA-B27 positive & 18 & $5(28)$ \\
HLA-B27 negative & 34 & $15(44)$ \\
Seronegative spondylarthropathies with diagnosed AS & 23 & $5(43)$ \\
Crohn's disease & 11 & $2(13)$ \\
Psoriatic arthritis & 15 & 0 \\
Rherogative spondylarthropathies without diagnosed AS & 29 & 0 \\
Healthy controls & 38 &
\end{tabular}

${ }^{*}$ AS = ankylosing spondylitis serum samples both from patients with rheumatoid arthritis and from apparently healthy controls did not show a positive reaction.

To test for a possible correlation between the presence of the antibody to the $36 \mathrm{kD}$ antigen and the expression of HLA-B27 we screened HLA-B27 positive and negative serum samples. In the patients with definite and suspected ankylosing spondylitis positive immune reactions with the $36 \mathrm{kD}$ antigen were found in 42 (35\%) of 120 HLA-B27 positive serum samples and in five out of 18 (28\%) HLA-B27 negative samples (table).

The presence of antibodies to the $36 \mathrm{kD}$ antigen in patients with ankylosing spondylitis seems to be independent of the patients' age, sex, and disease activity as indicated by erythrocyte sedimentation rate and radiological changes.

For further characterisation of the $36 \mathrm{kD}$ antigen the total $\mathrm{KC}$ protein was separated in two dimensional gels with non-equilibrium, $\mathrm{pH}$ gradient electrophoresis as first dimension and SDS-PAGE as second. This particular gel was blotted one after the other to three different nitrocellulose sheets. The first and third blot showed a single spot at $36 \mathrm{kD}$ and a basic $\mathrm{pH}$ reacting strongly with pooled ankylosing spondylitis serum samples, whereas the second blot did not show any reaction at all when incubated with a normal serum pool, thus proving the selective and highly specific reaction of the ankylosing spondylitis specific antibody (fig 3). Antibodies eluted from these spots in turn specifically reacted with the $36 \mathrm{kD}$ band in Western blots of total protein preparations of $\mathrm{KC}$ cells (data not shown). The $36 \mathrm{kD}$ protein showed an isoelectric point of 9.0 when focused under equilibrium conditions. When the serum of patients with ankylosing spondylitis and antibodies purified from the $36 \mathrm{kD}$ drosophila protein were applied to Western blots of human lymphocyte and HeLa proteins, a $69 \mathrm{kD}$ human antigen could be identified (figs $4 A$ and $B$ ). The eluted antibody was reincubated with a Western

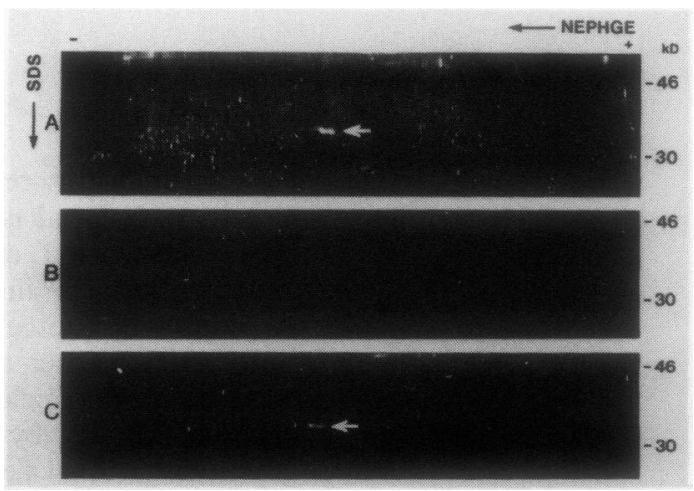

Figure 3 Reaction of the $36 \mathrm{kD}$ Drosphila protein selective and specific for ankylosing spondylitis. Two dimensional separation of total protein preparation of $K C$ cells: nonequilibrium, pH gradient electrophoresis (NEPHGE) and sodium dodecyl sulphate-polyacrylamide gel electrophoresis (SDS-PAGE). The gel was blotted to three different nitrocellulose filters $(A, B, C)$ for 20 minutes each. Blots $A$ and $C$ were reacted with pooled ankylosing spondylitis serum samples, whereas blot $B$ was incubated with a pool of normal serum samples as control. Detection of the bound human antibodies occurred with a fluorescein isothiocyanate conjugated sheep antihuman immunoglobuilin secondary antibody. Blots $A$ and $C$ show a strong signal at $36 \mathrm{kD}$ (arrows), whereas blot $B$ shows no signal. 


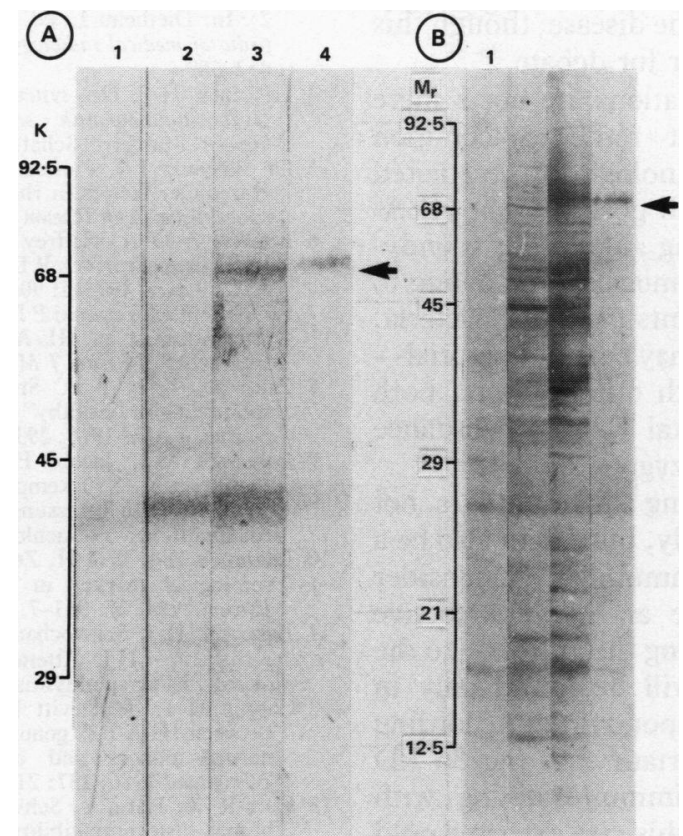

Figure 4 Reaction with $(A)$ a human lymphocyte protein and $(B) a$ HeLa protein specific for ankylosing spondylitis. Immunoblots of $(A)$ lymphocyte proteins and $(B) \mathrm{HeLa}$ proteins were incubated with pooled ankylosing spondylitis serum samples (lane 3), pooled normal control serum samples (lane 2), and antibodies eluted from the $36 \mathrm{kD}$ Drosophila melanogaster protein after reaction with pooled ankylosing spondylitis serum samples (lane 4). The reactions were visualised by a biotimylated secondary antibody, $a$ streptavidin-peroxidase complex, and diaminobenzidine. The pooled ankylosing spondylitis serum samples and the purified antibodies to the $36 \mathrm{kD}$ antigen show specific reactions with a $69 \mathrm{kD}$ lymphocyte and $a 69 \mathrm{kD}$ HeLa protein (arrows). Other bands visible on lane 4 are reactions of the secondary antibody. Lane 1, the control, shows the reaction of the secondary antibody alone.

blot identical to the one shown in fig 2. A single band of $36 \mathrm{kD}$ reacted, proving the quality and specificity of the eluted antibody (fig 5). Elution of the antibodies reacting with the $69 \mathrm{kD}$ human lymphocyte antigen and reincubation on KC protein immunoblots showed a specific reaction with a $36 \mathrm{kD}$ drosophila antigen (data not shown).

\section{Discussion}

The specificity and prevalence of the antibodies to the $36 \mathrm{kD}$ antigen, detectable in immunoblots of $D$ melanogaster and $D$ hydei protein preparations, as well as those reacting with the $93 \mathrm{D}$ heat shock puff substantially improve the chances of diagnosing ankylosing spondylitis and thus help to differentiate it from other systemic rheumatic diseases.

Introduction of these serological markers of ankylosing spondylitis aids the diagnostic process in the early stages and in women, who very often have a milder form of disease. Furthermore, the antibody to the $36 \mathrm{kD}$ antigen supports the identification of other 'seronegative' spondylarthropathies, which are characterised by symptoms of ankylosing spondylitis. According to these results, the 36 $\mathrm{kD}$ antibody could be used to identify patients with ankylosing spondylitis or related diseases, like psoriatic arthritis or inflammatory bowel disease.

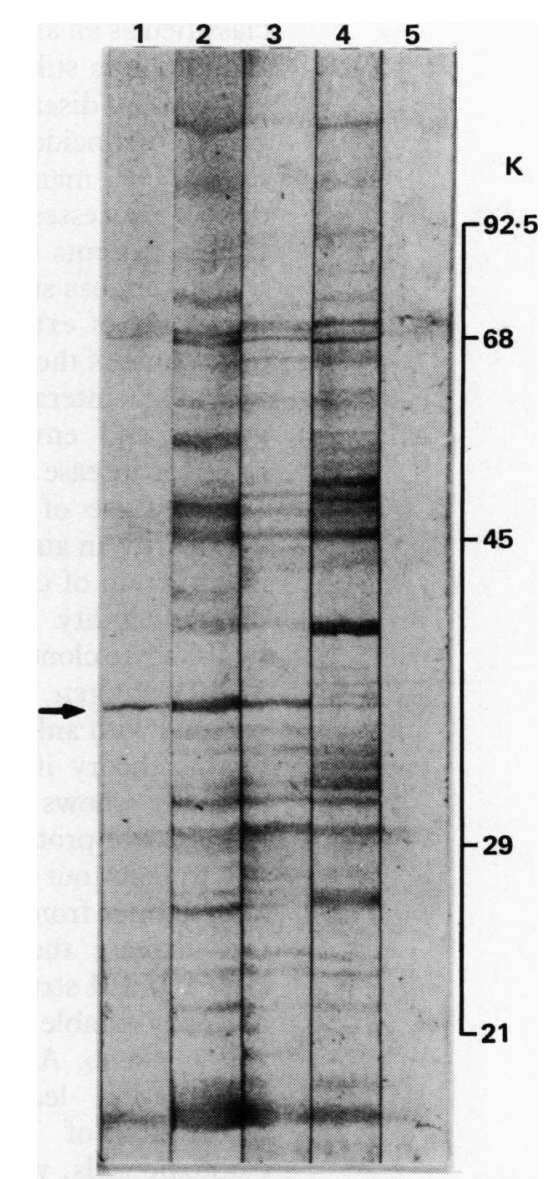

Figure 5 Quality of the eluted $36 \mathrm{kD}$ specific antibody. The immunoblot of Drosophila melanogaster proteins derived from the embryonic $K C$ cell line was incubated with antibodies purified from the reaction of ankylosing spondylitis serum samples with the $36 \mathrm{kD}$ protein (lane 1), a strongly reacting serum from a patient with ankylosing spondylitis (lane 2), a pool of ankylosing spondylitis serum samples (lane 3), and pooled normal control serum samples (lane 4). The reactions were visualised by a biotinylated secondary antibody, a streptavidin-peroxidase complex and diaminobenzidine. The serum samples from the pateints with ankylosing spondylitis and the purified antibodies to the 36 $k D$ antigen show a specific reaction with the $36 k D$ protein (arrow). Lane 5, the control, shows the reaction of the secondary antibody alone (lane 5).

Ankylosing spondylitis and other 'seronegative' spondylarthropathies are most tightly linked to the major histocompatibility complex (MHC) class I locus, the HLA-B27 haplotype. ${ }^{31} 32$ The molecule's function as a class I restriction element for cytotoxic lymphocytes is not altered by molecular variations of HLAB27: the diseases are associated with different variants of HLA-B27.

The $36 \mathrm{kD}$ antibodies are not linked to HLAB27, as can be judged from the fact that HLAB27 negative ankylosing spondylitis serum samples also react with the $36 \mathrm{kD}$ antigen. It has been suggested, however, that the basis of HLA-B27 disease association might be a nonfunctional contribution of an HLA-B27 sequence or a closely linked gene..$^{33-35}$ Using total protein preparations from human tissue, we were able to show for the first time that antibodies eluted from the $36 \mathrm{kD}$ drosophila antigen cross react on immunoblots with lymphocyte and HeLa proteins. This means that the $36 \mathrm{kD}$ antibody is an autoantibody and consequently, we feel ankylosing spondylitis should correctly be 
classified as an autoimmune disease, though this suggestion is still a matter for debate. .6-39 $^{36}$

As HLA disease associations are not a mere genetic coincidence, but rather a common feature of many immunologically mediated disease processes, it is still possible that HLAB27 in patients developing ankylosing spondylitis undergoes structural modification owing to the action of exterior agents (viruses, bacteria, etc). Cause of the disease may be multifactorialHLA-B27 interacting with other factors, both genetic and environmental (low concordance rates for disease in monozygotic twins.). ${ }^{40-42}$

The cause of ankylosing spondylitis is not necessarily an autoantibody, but might also be a malfunction of cellular immunity. We consider one possibility might be an immunoreactive lymphocyte clone producing the antibody to the $36 \mathrm{kD}$ antigen, which will be found only in patients with ankylosing spondylitis. According to this theory it is important that the $36 \mathrm{kD}$ antibody shows strong immunostaining with lymphocyte proteins. In this context we would like to point out that bacterially induced release of cytokines from $\mathrm{T}$ cells, especially interferon, can increase the expression of MHC coding class I and II structures in such a way that cells normally unable to present an antigen are now able to do so. A higher rate of foreign antigen presentation leads to local activation and maturation of $T$ and $B$ cells, and also of cytotoxic cells, which are non-MHC restricted. Normal cell surface structures in the neighbourhood of an MHC structure may now become immunogenic and cause autoaggressive reactions against normal cell antigens. ${ }^{43}$

The structure and function of the human antigens recognised by the antibodies specific for ankylosing spondylitis are still unknown. Preliminary results ${ }^{10} 1144$ show that the drosophila antigens are neither degradation products of a larger entity nor heat shock proteins or members of the well known RNP-for example, snRNP, proteins. Furthermore, the autoantibodies described here are definitely different from those reported by Schwimmbeck et al, ${ }^{45}$ which recognised the HLA-B27 antigens with a molecular weight of $45 \mathrm{kD}$ and $12 \mathrm{kD}$.

A prerequisite for the isolation of affinity purified monospecific $36 \mathrm{kD}$ antibodies is purification of the $36 \mathrm{kD}$ antigen by two dimensional gel electrophoresis. The monospecific antibodies are used for screening human expression vector libraries to obtain the respective human antigen as fusion protein. Analysis of the gene coding for this antigen will open the way for investigation of the pathogenesis and cause of ankylosing spondylitis and other 'seronegative' spondylarthropathies with symptoms of ankylosing spondylitis.

We thank Gerlind Heimeroth and Jutta Schulten for their technical assistance. Supported by a grant from the Bundesministerium für Forschung und Technologie (01 ZU 8602/8).

1 Bennett P H, Burch T A. New York symposium on population studies in rheumatic diseases: New York diagnostic criteria. Bull Rheum Dis 1967; 17: 435-58. 2 Moll J M H, Wright V. New York criteria for ankylosing 32: 354-63.

3 Schilling F. Roentgen diagnosis of the vertebral column (part
2). In: Diethelm L, ed. Spondylitis ankylopoetica. Encyclopedia of medical radiology. Vol VI. Berlin: Springer, 1974: 452-689.

4 Lakomek H-J. Der systemische Lupus erythematodes in der Differentialdiagnostik entzündlich rheumatischer Erkrankungen. Stuttgart: Schattauer, 1986.

5 De Blecourt J J, Polman A, De Blecourt-Meindersma T. Hereditary factors in rheumatoid arthritis and ankylosing spondylitis. Ann Rheum Dis 1961; 20: 215-23.

6 Brewerton D A, Caffrey M, Hart F D, James D C O, Nicholls A, Sturrock R D. Ankylosing spondylitis and HLA 27. Lancet 1973; i: 904-907.

7 Schlosstein L, Terasaki P I, Bluestone R, Pearson C M. High association of an HL-A antigen, W27, with ankylosing spondylitis. N Engl F Med 1973; 288: 704-6.

8 Calin A, Fries J F. Striking prevalence of ankylosing spondylitis in "healthy" W-27 positive males and females. N Engl F Med 1975; 293: 835-9.

9 Lakomek H-J, Jacobi E, Heydthausen M, Richter O, Husmann K, Krüskemper H L. Ein Rheumaregister zur systematischen Erfassung von Krankheitsbildern aus dem rheumatischen Formenkreis. Int Welt 1980; 7: 277-83.

10 Lakomek H-J, Will H, Zech M, Krüskemper H L. A new serological marker in ankylosing spondylitis. Arthritis Rheum 1984; 27: 961-7.

11 Lakomek H-J, Schwochau M, Decken K, Juli E, Will H, Krüskemper H L. Attempts towards a serological diagnosis of ankylosing spondylitis. Clin Rheumatol 1987; 6: 67-72.

12 Coppin H L, McDevitt H O. Absence of polymorphism between HLA-B27 genomic exon sequences isolated from normal donors and ankylosing spondylitis patients. f Immunol 1986; 137: 2168-72.

13 Karr R W, Hahn Y, Schwartz B D. Structural identity of human histocompatibility leucocyte antigen-B27 molecules from patients with ankylosing spondylitis and normal individuals. $f$ Clin Invest 1982; 69: 443-50.

14 Arnett F C, Edworthy S M, Bloch D A, et al. The American Rheumatism Association 1987 revised criteria for the Rheumatism Association 1987 revised criteria for the
classification of rheumatoid arthritis. Arthritis Rheum 1988; 31: $315-24$.

15 Echalier G, Ohanessian A. In vitro culture of Drosophila melanogaster embryonic cells. In Vitro 1970; 6: 162-72.

16 Echalier G. Drosophila cell culture and its application for the study of genetics and virology. II. Established diploid cell lines of Drosophila melanogaster as potential material for the study of genetics of somatic cells. Curr Top Microbiol Immunol 1971; 55: 220-7.

17 Sondermeijer P J A, Derksen J W M, Lubsen N H. Established cell lines of Drosphila hydei. In Vitro 1980; 16: 913-4.

18 Shields G, Sang J H. Improved medium for culture of drosophila embryonic cells. Drosophila Information Service 1977; 52: 161 .

19 Eagle $\mathbf{H}$. Amino acid metabolism in mammalian cell cultures. Science 1959; 130: 432-7.

20 Hanks J H, Wallace R E. Relation of oxygen and temperature in the preservation of tissues by refrigeration. Proc Soc Exp Biol Med 1949; 71: 196-200.

21 Bøyum A. Separation of white blood cells. Nature 1964; 204: $793-4$.

22 Bøyum A. Isolation of mononuclear cells and granulocytes from human blood. Scand $\mathcal{F}$ Clin Lab Invest 1968; 21 (supp 97): 77-89.

23 Laemmli U K. Cleavage of structural proteins during the assembly of the head of bacteriophage T4. Nature 1970; 227: $680-5$.

24 Kyhse-Andersen J. Electroblotting of multiple gels: a simple apparatus without buffer tank for rapid transfer of proteins from polyacrylamide to nitrocellulose. $\mathcal{F}$ Biochem Biophys Methods 1984; 10: 203-9.

25 Olmsted J B. Affinity purification of antibodies from diazotized paper blots of heterogeneous protein samples. $\mathcal{F}$ Biol Chem 1981; 256: 11955-7.

26 Smith D E, Fisher P A. Identification, developmenta regulation, and response to heat shock of two antigenically related forms of a major nuclear envelope protein in drosophila embryos: application of an improved method for affinity purification of antibodies using polypeptides
immobilized on nitrocellulose blots. $\mathcal{f}$ Cell Biol 1984; 99: 20-8.

27 O'Farrell P H. High resolution two-dimensional electrophoresis of proteins. F Biol Chem 1975; 250: 4007-21

28 O'Farrell P Z, Goodman H M, O'Farrell P H. High resolution two-dimensional electrophoresis of basic as wel as acidic proteins. Cell 1977; 12: 1133-42.

29 Sanders M M, Groppi V E, Browning E T. Resolution of basic cellular proteins including histone variants by twodimensional gel electrophoresis: evaluation of lysine to arginine ratios and phosphorylation. Anal Biochem 1980 103: $157-65$.

30 Wilks A F, Knowler J T. The analysis of the proteins of heterogeneous ribonucleoprotein particles on twodimensional polyacrylamide gels. Electrophoresis 1980; 1 : dimens 8 .

31 Arnett F C. Seronegative spondylarthropathies. Bull Rheum Dis 1987; 37: 1-12.

32 Møller P. Genetics of ankylosing spondylitis, psoriatic arthritis and Reiter's syndrome. Clin Exp Rheumatol 1987; 5 (suppl 1): 35-40.

33 Bell J I, Todd J A, McDevitt $\mathbf{H}$ O. The molecular basis of HLA-disease association. In: Harris H, Hirschhorn K, eds Advances in human genetics. New York: Plenum Press, 1989: $1-41$.

34 Khan M A. Immunogenetics of ankylosing spondylitis: 
clinically oriented aspects. Clin Exp Rheumatol 1987; 5 (suppl 1): 49-52.

35 Calin A. The spondylarthropathies: clinical aspects. Clin Exp Rheumatol 1987; 5 (suppl 1): 53-9.

36 Eghtedari A A, Davis P, Bacon P A. Immunological reactivity in ankylosing spondylitis. Ann Rheum Dis 1976; 35: $155-7$.

37 Fan P T, Clements P J, Yu D T Y, Opelz G, Bluestone R. Lymphocyte abnormalities in ankylosing spondylitis. Ann Rheum Dis 1977; 36: 471-3.

38 Kinsella T D. Correlative studies of lymphocyte transformation and plasma protein levels in ankylosing spondylitis. mation and plasma protein levels in ankylosing spondylitis.

39 Kinsell T D Esping

Kinsella T D, Espinoza L, Vasey F B. Serum complement and immunoglobulin levels in sporadic and familial ankylosing spondylitis. 7 Rheumatol 1975; 2: 308-13.

40 Moll J M H. Pathogenic mechanism of B27 related seronegative polyarthritis: interplay between genetic and environmental factors. Clin Exp Rheumatol 1987; 5 (suppl 1): $7-14$
41 Albert E, Scholz S. Immunogenetics and rheumatic disease. Clin Exp Rheumatol 1987; 5 (suppl 1): 29-34.

42 Linssen A, Rothova A, Broekema N, et al. Genes on chromosome $14 \mathrm{q}$ and their role in the pathogenesis of HLA-B27 associated diseases. Clin Exp Rheumatol 1987; 5 (suppl 1): 89-95.

43 Leibold W, Einfluss von Bakterien auf Lymphozyten: Pathogenetische Bedeutung für chronische Gelenkentzündungen. In: Deicher $\mathbf{H}$, ed. Pathomechanismen entzündlicher rheumatischer Erkrankungen bei Mensch und Tier. Weinheim: VCH Verlagsgesellschaft, 1989: 233-50.

44 Decken $K$. Versuche zur Isolation und Charakterisierung von Antigenen, die für definierte rheumatische Krankheiten
spezifisch sind [thesis]. Germany: Universität Düsseldorf, 1986.

45 Schwimmbeck P L, Yu D T Y, Oldstone M B A. Autoantibodies to HLA B27 in the sera of HLA B27 patients with ankylosing spondylitis and Reiter's syndrome. $\exists$ Exp Med 1987; 166: 173-81. 